\title{
Vasoprotective Agent
}

National Cancer Institute

\section{Source}

National Cancer Institute. Vasoprotective Agent. NCI Thesaurus. Code C123418.

Any agent that is used to prevent or inhibit damage to blood vessels. 